\title{
PENGARUH MOTIVASI KERJA, KEPUASAN KERJA, DAN KOMPENSASI TERHADAP DISIPLIN KERJA KARYAWAN KONTRAK DI POLITEKNIK NEGERI JAKARTA DEPOK JAWA BARAT
}

\author{
Mulyanto dan Lenny C. Nawangsari \\ Politeknik Negeri Jakarta, Universitas Mercu Buana \\ prisonbreak68@yahoo.co.id
}

\begin{abstract}
Abstrak. Tujuan penelitian ini adalah untuk menganalisis pengaruh motivasi kerja, kepuasan kerja, kompensasi terhadap disiplin kerja karyawan kontrak Politeknik Negeri Jakarta. Dsiplin karyawan adalah faktor yang sangat penting bagi setiap perusahaan atau lembaga di setiap negara di dunia. Disiplin dapat menentukan kultur organisasi, a yang baik, pencegahan penyimpangan, dan pada akhirnya menghasilkan kinerja organisasi. Hal ini mendorong ketertarikan untuk meninjau lebih jauh tentang variabel-variabel yang menentukan disiplin karyawan. Obyek penelitian adalah karyawan kontrak Pokiteknik negri jakarta (PNJ) Depok, Jawa Barat. Latar belakang pemilihan obyek karyawan kontrak karena mereka tidak memiliki jaminan seperti yang dimiliki oleh karyawan tetap seperti asuransi kesehatan, tunjangan cuti melahirkan, dan tentu saja jaminan kepastian pekerjaan. Kondisi status pekerjaan kontrak seperti tersebut diatas cendrung berdampak negatif terhadap motivasi kerja, kepuasan kerja, yang pada akhirnya berdampak pada disiplin kerja. Dengan melakukan riset pendahuluan, dengan menggunakan instrumen kuesioner terhadap 40 karyawan kontrak, diperoleh bahwa variabel motivasi kerja, kepuasan kerja, dan kompensasi, merupakan variabel-variabel bebas utama yang mampu mempengaruhi disiplin kerja sebagai variabel terikat, sehingga penelitian ini unyuk menguji pengaruh motivasi kerja, kepuasan kerja, dan kompensasi terhadap disiplin kerja karyawan kontrak PNJ. Setelah melakukan pengolahan dan anlisis data ats kuesioner mengenai percepsi karyawan kontrak PNJ, dengan jumlah sampel 91 responden dari 117 popujasi, terhadap 4 variabel yaitu motivasi kerja, kepuasan kerja, kompensasi, dan disiplin kerja, maka disimpulkan secara komprehensif bahwa secara individual ketiga variabel bebas berkorelasi positif terhadap disiplin kerja. Demikian pula secara simultan berkorelasi positif terhadap disiplin kerja karyawan kontrak Politeknik Negeri Jakarta.
\end{abstract}

Kata Kunci: Disiplin kerja, Kepuasan kerja, motivasi kerja, kompensasi, karyawan kontrak.

\begin{abstract}
The purpose of this reaserch is to analyze the influence of job motivation, job satisfaction, and job compensation to job dicipline of contracted employees in Politeknik Negeri Jakarta. Diciplin of employee is a very important factor for any corporation or entity in all over countries. Diciplne may determine organization culture, good governments, prevent descripancies, and at the end generate organization performance. So there is such curiousity to find out what variables may influence dicipline. The object of resarch is the contract employees of Politeknik Negeri Jakarta (PNJ) Depok, West Java. The reason took contracted employee is because they dont have insurance of health, delivery leave, and obviously permanent job. These condition tend to effect negatively to motivation, satisfaction, and finally to dicipline. By doing some pre-research, , by distributing questionare to 40 contracted employees, it discovered that job motivation, job satisfaction, and job compensation are determinant independant variables to job dicipline as dependant variable, so this studi is to eximining the influence jo motivation, job satisfaction, and compentation to job dicipline contracted employee of PNJ. After overviewing some data on questioner distributed about perception of four variables ( job motivation, job satisfaction, compensation ) over 91 samples of 117 population respndents of contracted employees, this research comprehensively come into conclutionn that individually job motivation has, job satifaction, compensation has strong positive correlation to work dicipline and simultanously also define strong positive correlation to work dicipline of cotracted employees of Politeknik Negeri Jakarta
\end{abstract}


Keywords: dicipline, job motivation, job satisfaction, compensation, contracted employee

\section{PENDAHULUAN}

Mewujudkan standar pelayanan yang prima, institusi pendidikan tinggi harus memiliki SDM yang kompeten dan terampil di unit kerja masing-masing. Keterbatasan anggaran mengakibatkan tidak dimungkinkannya suatu institusi mempekerjakan pegawai tetap, melainkan tenaga honorer atau kontrak. Namun perbedaan kedua karakter sumber daya manusia ini merupakan keniscayaan dalam aspek-aspek komitmen, tanggung jawab, dan integritas. Hal ini disebabkan adanya perbedaan kompensasi berupa promosi, insentif dan tunjangan pasca kerja yang tidak dimiliki oleh pegawai honorer atau kontrak. Seluruh karyawan kontrak dan honorer ditempatkan pada bidang operasional seperti staf administrasi yang berhubungan dengan surat-menyurat, kehumasan, pemeliharaan, satpam, helper, dan kebersihan. Jenis pelayanan bidang-bidang pekerjaan tersebut sangat vital karena dibutuhkan okeh pengguna jasa setiap hari seperti manajemen, dosen, dan mahasiswa.

Berdasarkan data dari Biro kepegawaian PNJ rata-rata standar kehadiran normal karyawan adalah 22 hari dalam 1 bulan, jika kehadiran kurang dari 22 hari akan berpengaruh pada kompensasi yang diterima selain tunjangan tetap. Dari hasil wawancara yang dilakukan pada beberapa unit kerja dan jurusan di PNJ diperoleh informasi keluhan tentang gangguan operasional yang menghambat kelancaran aktivitas akademik seperti air, listrik, AC, komputer, dan kebersihan.

Berdasarkan hasil prasurvey yang penulis lakukan terhadap 40 orang pegawai menemukan bahwa masih ada beberapa faktor yang tidak terpenuhi secara penuh dari pandangan perspektif karyawan kontrak di Politeknik Negeri Jakarta. Adapun faktor faktor itu adalah motivasi kerja yang hanya sebesar 63\% sehingga karyawan tidak memiliki motivasi untuk melakukan kreatifitas dalam bekerja, disiplin kerja yang hanya sebesar $75 \%$ artinya karyawan belum mampu menyelesaikan sesuai dengan waktu yang telah ditentukan, dan kepuasan kerja karyawan yang hanya sebesar $81 \%$ belum mampu meningkatkan disiplin kerja karyawan di PNJ.

Sesuai dengan hasil penelitian terdahulu yang dilakukan oleh Prabu (2005), Koesmono (2005), Ayu dan Suprayetno (2008) yang menemukan bahwa motivasi berpengaruh signifikan terhadap disiplin kerja. Hasil penelitian Hasibuan (2003) yang menyatakan bahwa seseorang cenderung bekerja dengan penuh semangat apabila kepuasan dapat diperolehnya dari pekerjaannya dan kepuasan kerja karyawan merupakan kunci pendorong moral, kedisiplinan, serta prestasi kerja karyawan dalam mendukung terwujudnya tujuan perusahaan. Pegawai yang puas saat bekerja pada perusahaannya, berkontribusi positif bagi peningkatan kinerjanya. Selanjutnya Asfar Halim Dalimunthe dalam penelitiannya menyatakan terdapat hubungan yang cukup kuat antara budaya organisasi dengan disiplin kerja. Gde Bayu Surya (2013) dalam studinya pada dosen Yayasan Universitas Mahasaraswati Denpasar menyatakan terdapat pengaruh positif dan signifikan antara komitmen organisasi dan disiplin kerja.

Berdasarkan permasalah yang terjadi, maka dilakukan penelitian mengenai pengaruh motivasi kerja, kepuasan kerja dan kompensasi terhadap disiplin karyawan kontrak dilingkungan Politeknik Negeri Jakarta.

Adapun tujuan penelitian ini adalah:

1. Mengetahui dan menganalisis pengaruh motivasi kerja terhadap disiplin kerja karyawan.

2. Mengetahui dan menganalisis pengaruh kepuasan kerja terhadap disiplin kerja karyawan. 
3. Mengetahui dan menganalisis pengaruh kompensasi terhadap disiplin kerja karyawan.

4. Mengetahui dan menganalisis pengaruh secara simultan motivasi kerja, kepuasan kerja dan kompensasi terhadap disiplin kerja karyawan.

\section{KAJIAN TEORI}

Disiplin Kerja. Menurut James Drever (1952) dari sisi psikologis, disiplin adalah kemampuan mengendalikan perilaku yang berasal dari dalam diri seseorang sesuai dengan hal-hal yang telah di atur dari luar atau norma yang sudah ada. Sedangkan menurut Pratt Fairshild (1994) dari sisi sosiologi, disiplin terdiri dari dua bagian, yaitu disiplin dari dalam diri dan juga disiplin sosial.

Motivasi Kerja. Menurut Mc Clelland seseorang dianggap mempunyai motivasi apabila dia mempunyai keinginan berprestasi lebih baik dari pada yang lain. Menurut Reksohadiprojo dan Handoko (1996 : 85) pada banyak situasi Mc Clelland menguatkan pada tiga kebutuhan,yaitu: 1) Kebutuhan prestasi, tercermin dari keinginan mengambil tugas yang dapat dipertanggungjawabkan secara pribadi atas perbuatan-perbuatannya. Ia menentukan tujuan yang wajar dapat memperhitungkan resiko dan ia berusaha melakukan sesuatu secara kreatif dan inovatif. 2) Kebutuhan afiliasi, kebutuhan ini ditujukan dengan adanya kondisi bersahabat dalam lingkungan kerja. 3) Kebutuhan kekuasaan, kebutuhan ini tercermin pada seseorang yang ingin mempunyai pengaruh atas orang lain, dia peka terhadap struktur pengaruh antar pribadi dan ia mencoba menguasai orang lain dengan mengatur perilakunya dan membuat orang lain terkesan kepadanya, serta selalu menjaga reputasi dan kedudukannya.

\section{Kerangka Pemikiran.}

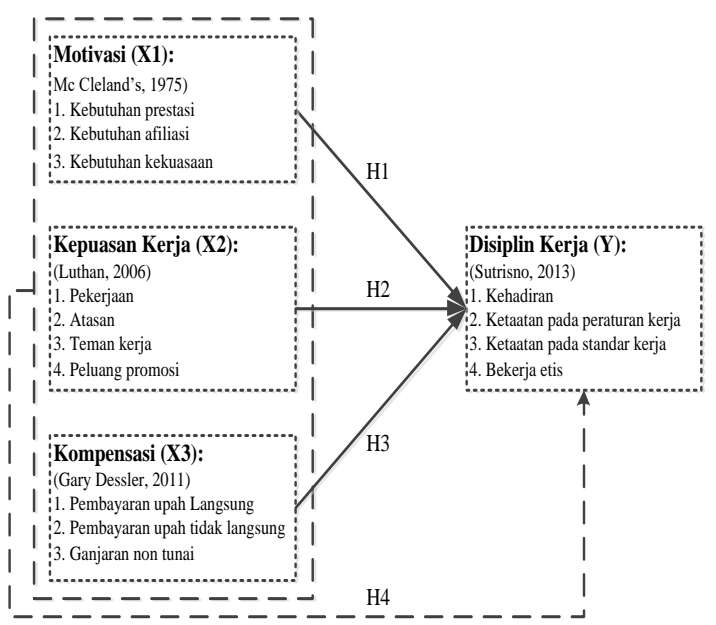

\section{Gambar 1. Kerangka Pemikiran}

\section{Hipotesis.}

$\mathrm{H}_{1}$ : Motivasi berpengaruh terhadap disiplin kerja karyawan kontrak Politeknik Negeri Jakarta

$\mathrm{H}_{2}$ : Kepuasan kerja berpengaruh terhadap disiplin kerja karyawan kontrak Politeknik Negeri Jakarta

$\mathrm{H}_{3}$ : Kompensasi berpengaruh terhadap disiplin kerja karyawan kontrak Politeknik Negeri Jakarta

$\mathrm{H}_{4}$ : Motivasi, kepuasan kerja dan kompensasi secara simultan bepengaruh terhadap disiplin kerja karyawan kontrak Politeknik Negeri Jakarta

\section{METODE}

Jenis Penelitian. Penelitian ini menggunakan jenis penelitian deskriptif kuantitatif yang merupakan penelitian yang bertujuan untuk memperoleh deskripsi tentang ciri- ciri variabel penelitian. Variabel dalam penelitian ini terdiri dari variabel bebas (kepuasan kerja, motivasi kerja, kompensasi) dan variabel terikat (disiplin karyawan).

Definisi Operasional Variabel. Definisi operasional merupakan penjabaran konsep atau variabel penelitian dalam rincian yang terukur (indikator penelitian). Tujuan adanya definisi operasional agar setiap variabel yang digunakan dalam penelitian ini dapat dipahami secara lebih mendalam, dan dapat mempermudah dalam membuat 
indikato-indikator sehingga variabel tersebut dapat diukur.

Variabel Motivasi Kerja (X1) untuk dapat diukur pengaruhnya dalam penelitian maka dijelaskan kedalam tiga dimensi yaitu dimensi: 1) Kebutuhan Prestasi yang terdiri dari tiga indikator pengukuran yaitu melakukan sesuatu dengan cara baru dan kreatif, mengambil tanggungjawab atas pekerjaan, dan berani mengambil resiko atas pekerjaan. 2) Kebutuhan Afiliasi yang terdiri dari indikator seberapa jauh hubungan sosial antar karyawan, tingkat rasa saling membutuhkan, dan kerjasama yang prima mencapai kinerja. 3) Dimensi kebutuhan kekuasaan yang terdiri dari indikator kemampuan mengkoordinir tim, rasa tanggungjawab dalam menyelesaikan kerja tim, dan frekuensi memberi solusi.

Variabel Kepuasan Kerja (X2) terdiri dari lima dimensi pengukuran yaitu 1) Pekerjaan terdiri dari indikator (a) Seberapa jauh pekerjaan tersebut tetap dapat meyibukkan individu, (b) Kewenangan untuk dapat bekeja sendiri, (c) Kesempatan untuk melakukan pekerjaan yang berbeda-beda, (d) Pengakuan masyarakat luas tentang status pekerjaan, (e) Kepastian kerja yang diberikan, dan (f) Kesempatan untuk menggunakan kemampuan yang ada, 2) Dimensi atasan terdiri dari indikator kemampuan atasan dalam menjalin hubungan interpersonal, kemampuan atau skill atasan menyangkut segala sesuatu yang berhubungan dengan pekerjaan, dan seberapa jauh perusahaan menyenangkan para pekerja, 3) Dimensi Teman Kerja terdiri dari indikator seberapa baik hubungan antara sesama rekan kerja, dan kesempatan untuk membantu orang lain mengerjakan tugas, 4) Dimensi Peluang Promosi terdiri dari proses kenaikan jabatan yang tebuka bedasarkan prstasi, perusahaan punya prospek yang baik, dan adanya hubungan fungsional yang positif, 5) Dimensi Working Condition terdiri dari tempat kerja yang nyaman, pekerjaan tidak membahayakan, dan dekorasi ditempat kerja.

Variabel Kompensasi (X3) terdiri dari tiga dimensi pengukuran yaitu 1)
Pembayaran upah secara langsung terdiri dari indikator gaji yang sesuai dan bonus yang sesuai. 2) Pembayaran upah secara tidak langsung terdiri dari indikator adanya jaminan kesehatan, adanya fasilitas pinjaman dari perusahaan, dan adanya promosi jabatan. 3) Dimensi Ganjaran non tunai terdiri dari indikator pekerjaan yang lebih menantang, dan pengakuan atas hasil kerja.

Variabel Disiplin Kerja (Y) terdiri dari tiga dimensi pengukuran yaitu 1) Kehadiran terdiri dari indikator datang ke tempat kerja tepat waktu, pulang kerja sesuai aturan perusahaan, dan penyelesaian pekerjaan tepat waktu. 2) Dimensi Taat terhadap Peraturan Perusahaan terdiri dari indikator pemahaman tentang peraturan perusahaan, pelaksanaan pekerjaan sesuai peraturan perusahaan, dan ketaatan pada peraturan perusahaan. 3) Dimensi Taat terhadap Standar terdiri dari indikator bertingkah laku yang baik, bertanggung jawab terhadap hasil kerja, dan bersedia menerima sanksi.

Populasi dan Sampel. Populasi dalam penelitian ini adalah seluruh karyawan kontrak Politeknik Negeri Jakarta yang berjumlah 117 orang. Menggunakan rumus Slovin dengan tingkat kesalahan yang ditoleransi adalah sebesar 5\%, maka jumlah sampel yang digunakan dalam penelitian ini adalah sebanyak 91 orang responden.

\section{Metode Pengumpulan dan Analisis Data.} Metode pengumpulan data yang dilakukan dalam penelitian ini adalah dengan menyebar kuisoner dan wawancara. Wawancara dilakukan dengan maksud untuk mendapatkan data awal yang bertujuan untuk mendapatkan informasi yang lebih mendetail dalam hubungannya dengan subyek penelitian dan obyek penelitian. Dan kemudian dilanjutkan dengan menyebar kuisoner pada para karyawan yang telah dipilih secara acak disetiap divisi.

Sedangkan teknik analisis data dalam penelitian ini dilakukan dengan menggunakan beberapa metode analisa dan dengan bantuan SPSS. 
HASIL DAN PEMBAHASAN

Uji Instrumen Penelitian. Menguji instrument penelitian dilakukan dengan dua cara yaitu uji validitas dan uji reliabilitas. Berdasarkan hasil pengujian disimpulkan bahwa seluruh instrumen penelitian dari masing - masing variabel motivasi kerja, kepuasan kerja, kompensasi dan disiplin kerja bersifat valid dan reliable karena diperoleh nilai $\mathrm{r}_{\text {hitung }}$ lebih besar dari nilai $r_{\text {tabel }}(>0,2027)$ dan nilai Cronbach Alpha lebih besar dari 0,60.

Tabel 1. Hasil Uji Instrumen Penelitian

\begin{tabular}{llclll}
\hline \multicolumn{1}{c}{ Variabel } & $\begin{array}{c}\text { Jumlah } \\
\text { Pertanyaan }\end{array}$ & Rhitung & Rtabel & $\begin{array}{c}\text { Cronbach } \\
\text { Alpha }\end{array}$ & Keputusan \\
\hline Motivasi Kerja & 9 & $0,340-0,751$ & 0,2027 & 0.817 & $\begin{array}{l}\text { Valid dan } \\
\text { Reliable } \\
\text { Valid dan }\end{array}$ \\
Kepuasan Kerja & 17 & $0,377-0,711$ & 0,2027 & 0.902 & $\begin{array}{l}\text { Reliable } \\
\text { Valid dan } \\
\text { Reliable } \\
\text { Kompensasi }\end{array}$ \\
Tisiplin Kerja & 9 & $0,290-0,617$ & 0,2027 & 0.750 & $\begin{array}{l}\text { Valid dan } \\
\text { Reliable }\end{array}$ \\
\hline
\end{tabular}

Tabel 3. Hasil Uji Multikolinieritas

Uji Normalitas. Uji normalitas pada penelitian ini menggunakan metode Kolmogorov Smirnov. Uji normalitas dengan metode Kolmogorov Smirnov menghasilkan nilai signifikansi atau Asymp. Sig lebih besar dari 0,05 sehingga dapat disimpulkan bahwa data terdistribusi normal.

Tabel 2. Hasil Uji Normalitas One-Sample Kolmogorov-Smirnov Test

\begin{tabular}{llrrrr}
\hline & & X1 & X2 & X3 & \multicolumn{1}{c}{$\mathrm{Y}$} \\
\hline $\mathrm{N}$ & & 91 & 91 & 91 & 91 \\
\hline Normal & Mean & 29.86 & 59.22 & 27.36 & 31.51 \\
Parameters & Std. & & & & \\
& Deviation & 6.382 & 11.748 & 5.984 & 6.938 \\
Most & Absolute & .137 & .095 & .102 & .128 \\
Extreme & Positive & .088 & .065 & .101 & .088 \\
Differences & Negative & -.137 & -.095 & -.102 & -.128 \\
Kolmogorov-Smirnov & 1.307 & .909 & .973 & 1.225 \\
Z & & & & \\
Asymp. Sig. (2-tailed) & $\mathbf{. 0 6 6}$ & $\mathbf{. 3 8 0}$ & $\mathbf{. 3 0 0}$ & $\mathbf{. 1 0 0}$ \\
\hline
\end{tabular}

Uji Multikolinieritas. Pengujian ini bertujuan untuk mengetahui sejauh mana terjadinya korelasi diantara sesama variabel bebas. Hasil uji dapat dilihat pada tabel 3 dibawah ini, terlihat bahwa semua nilai VIF $\mathrm{X} 1$, X2, dan X3 $(3.366,2.427$, dan 2.829) < 10, sehingga dalam korelasi ini tidak terjadi multikolinieritas.

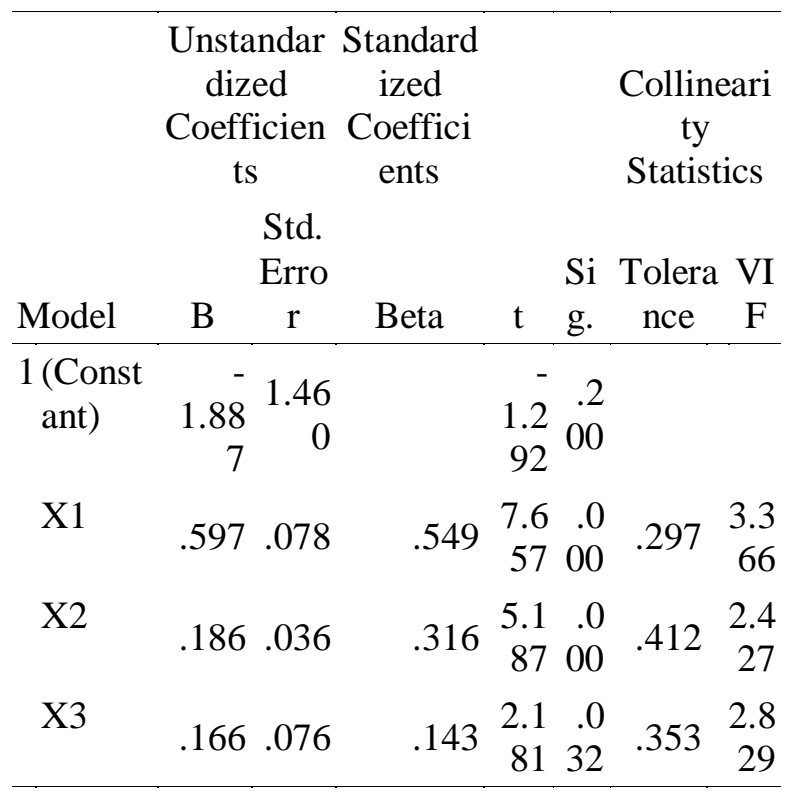

a. Dependent

Variable: Y

Uji Heteroskedastisitas. Salah satu metode uji heteroskedastisitas adalah dengan melihat pola grafik scatterplot. Hasil pengujian menunjukan data tidak membentuk suatu pola tertentu, dan titik - titik data menyebar diatas dan dibawah angka 0 sumbu vertikal Y, sehingga dapat disimpulkan bahwa tidak terjadi heteroskedastisitas. 


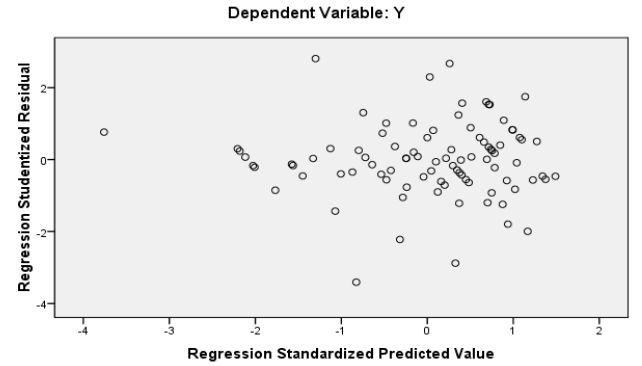

Gambar 2. Hasil Uji Heteroskedastisitas

\section{Uji Hipotesis}

Uji F. Hasil pengujian uji $F$, uji t, regresi linier berganda, dan uji $\mathrm{r}$ seperti terlihat pada tabel 4 dibawah:

Tabel 4. Hasil Uji F

\begin{tabular}{lrrrrr}
\multicolumn{6}{c}{ ANOVA $^{\mathbf{b}}$} \\
\hline & $\begin{array}{c}\text { Sum of } \\
\text { Model }\end{array}$ & \multicolumn{2}{c}{ Mean } & & \\
\hline Squares df & Square & \multicolumn{1}{c}{ F } & Sig. \\
\hline Regressio & 3753.81 & & 1251.27 & 188.03 & .000 \\
n & 3 & 1 & 6 & a \\
Residual & 578.934 & 8 & 6.654 & & \\
& & 7 & & & \\
Total & 4332.74 & 9 & & & \\
& 7 & 0 & & &
\end{tabular}

a. Predictors: (Constant),

$\mathrm{X} 3, \mathrm{X} 2, \mathrm{X} 1$

b. Dependent

Variable: Y

Hasil perhitungan SPSS seperti pada tabel 4 diatas, didapat Nilai Sig $=0,000$ dan $\mathrm{F}$ hitung $=188,036$. Karena sig $<0,05$ maka, terdapat pengaruh motivasi, kepuasan kerja dan kompensasi secara simultan terhadap disiplin kerja karyawan kontrak Politeknik Negeri Jakarta.

Uji t. Pada tabel 5 dibawah ini terlihat bahwa variabel X1 (Motivasi kerja) hasil perhitungan SPSS didapat Nilai Sig $=0,000$ dan t hitung $=7,754$. Karena sig $<0,05$ maka terdapat pengaruh motivasi terhadap disiplin kerja karyawan kontrak Politeknik Negeri Jakarta. Selanjutnya untuk Variabel X2 (Kepuasan kerja) hasil perhitungan SPSS didapat Nilai $\mathrm{Sig}=0,000$ dan $\mathrm{t}$ hitung $=$
5,222. karena sig $<0,05$ maka terdapat pengaruh kepuasaan kerja terhadap disiplin kerja karyawan kontrak Politeknik Negeri Jakarta. Dan untuk hasil perhitungan SPSS pada variabel X3 (Kompensasi) didapat Nilai $\mathrm{Sig}=0,045$ dan $\mathrm{t}$ hitung $=2,033$. Karena sig $<0,05$ maka terdapat pengaruh kompensasi terhadap disiplin kerja karyawan kontrak Politeknik Negeri Jakarta.

\section{Tabel 5. Hasil Uji t dan Regresi Linier Berganda Coefficients $^{\text {a }}$}

\begin{tabular}{|c|c|c|c|c|c|}
\hline \multirow[b]{2}{*}{ Model } & $\begin{array}{r}\text { Unstan } \\
\text { e } \\
\text { Coeff }\end{array}$ & $\begin{array}{l}\text { dardiz } \\
\text { d } \\
\text { cients }\end{array}$ & $\begin{array}{c}\begin{array}{c}\text { Standardiz } \\
\text { ed } \\
\text { Coefficient } \\
\text { s }\end{array} \\
\end{array}$ & \multirow[b]{2}{*}{$\mathbf{t}$} & \multirow[b]{2}{*}{$\begin{array}{c}\text { Sig } \\
\text {. }\end{array}$} \\
\hline & $\mathbf{A}$ & $\begin{array}{l}\text { Std. } \\
\text { Error }\end{array}$ & $\beta$ & & \\
\hline $\begin{array}{c}\text { (Constan } \\
\text { t) }\end{array}$ & -1.897 & 1.469 & & $\begin{array}{c}- \\
1.29 \\
1\end{array}$ & $\begin{array}{c}.20 \\
0\end{array}$ \\
\hline $\mathrm{X} 1$ & .604 & .078 & .555 & $\begin{array}{c}7.75 \\
4\end{array}$ & $\begin{array}{c}.00 \\
0\end{array}$ \\
\hline $\mathrm{X} 2$ & .188 & .036 & .318 & $\begin{array}{c}5.22 \\
2\end{array}$ & $\begin{array}{c}.00 \\
0\end{array}$ \\
\hline $\mathrm{X} 3$ & .155 & .076 & .133 & $\begin{array}{c}2.03 \\
3\end{array}$ & $\begin{array}{c}.04 \\
5\end{array}$ \\
\hline $\begin{array}{l}\text { a. Depen } \\
\text { Variabl }\end{array}$ & $\begin{array}{l}\text { adent } \\
\text { e: Y }\end{array}$ & & & & \\
\hline
\end{tabular}

Analisis Regresi Linear Berganda. Untuk mengetahui prediksi perubahan nilai variabel dependen (Y) yang diakibatkan oleh perubahan nilai variabel independen (X1, $\mathrm{X} 2$, dan X3 ) maka digunakan analisis Regresi Linear Berganda.

Berdasarkan tabel 5 diatas maka dapat dibuat persamaan regresi linear berganda:

$$
\begin{aligned}
& \hat{Y}=\alpha_{0}+\beta_{1} X_{1}+\beta_{2} X_{2}+\beta_{3} X_{3} \\
& \hat{Y}=-1,897+0,604 X_{1}+0,188 X_{2}+ \\
& 0,155 X_{3}
\end{aligned}
$$

Artinya adalah setiap kenaikan satu unit variabel motivasi akan meningkatkan disiplin kerja sebesar 0,604, setiap kenaikan satu unit kepuasaan kerja akan meningkatkan disiplin kerja sebesar 0,188, 
dan setiap kenaikan satu unit variabel kompensasi akan meningkatkan displin kerja sebesar 0,155 , tetapi apabila tidak ada variabel motivasi, kepuasaan kerja, dan kompensasi maka disiplin kerja akan tetap sebesar $-1,897$.

Koefisien $\mathbf{R}$ Square. Berdasarkan hasil perhitungan pada tabel 6 dibawah ini, nilai hubungan antara motivasi, kepuasan kerja dan kompensasi dengan disiplin kerja karyawan kontrak Politeknik Negeri Jakarta adalah sebesar 0,866. Sehingga dapat disimpulkan bahwa variabel motivasi, kepuasan kerja dan kompensasi memberikan sumbangan terhadap peningkatan variabel disiplin kerja karyawan kontrak Politeknik Negeri Jakarta sebesar 86,6 \% dan sisanya $13,4 \%$ dari variabel lain.

\section{Tabel 6. Hasil Uji R Square}

Model Summary

\begin{tabular}{lrrrr}
\hline Model & $\mathbf{R}$ & $\begin{array}{c}\mathbf{R} \\
\text { Square }\end{array}$ & $\begin{array}{r}\text { Adjusted } \\
\text { R Square }\end{array}$ & $\begin{array}{l}\text { Std. Error of } \\
\text { the Estimate }\end{array}$ \\
\hline 1 & $.931^{\text {a }}$ & .866 & .862 & 2.580 \\
a. Predictors: & (Constant), X3, & \\
X2, X1 & & & \\
\hline
\end{tabular}

Korelasi antar dimensi.

Tabel 7. Matriks Korelasi antar Dimensi

Disiplin Kerja Karyawan

Taat

Tehada Taat

\begin{tabular}{|c|c|c|c|c|}
\hline $\begin{array}{l}\text { Variabe } \\
\text { I Bebas }\end{array}$ & Dimensi & $\begin{array}{l}\text { Kehadi } \\
\text { ran }\end{array}$ & $\begin{array}{c}p \\
\text { Peratur } \\
\text { an } \\
\text { Perusah } \\
\text { aan }\end{array}$ & $\begin{array}{c}\text { Terha } \\
\text { dap } \\
\text { Standa } \\
\mathbf{r}\end{array}$ \\
\hline \multirow{3}{*}{$\begin{array}{l}\text { Motivasi } \\
\text { (X1) }\end{array}$} & $\begin{array}{l}\text { Kebutuh } \\
\text { an } \\
\text { Prestasi }\end{array}$ & 0,689 & 0,572 & 0,279 \\
\hline & $\begin{array}{l}\text { Kebutuh } \\
\text { an } \\
\text { Afiliasi }\end{array}$ & 0,638 & 0,686 & 0,473 \\
\hline & $\begin{array}{l}\text { Kebutuh } \\
\text { an } \\
\text { Kekuasa } \\
\text { an }\end{array}$ & 0,524 & 0,584 & 0,789 \\
\hline
\end{tabular}

\begin{tabular}{lllll}
\hline Kepuasa & Pekerjaa & $\mathbf{0 , 7 0 0}$ & 0,671 & 0,413
\end{tabular}

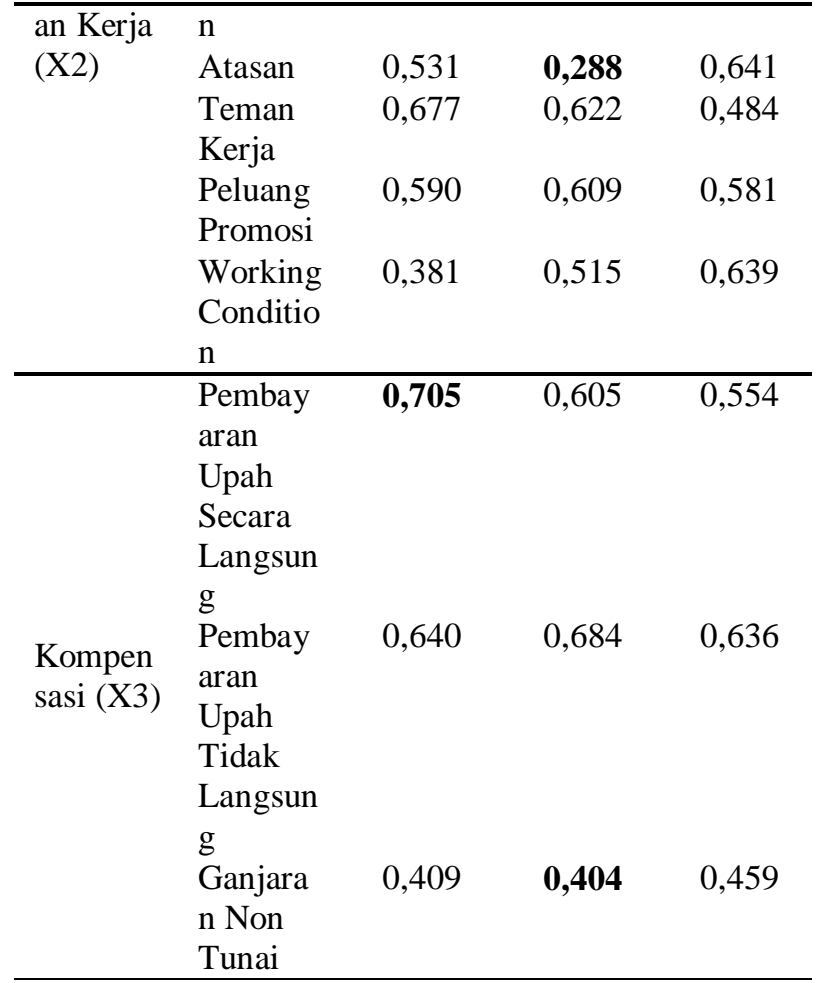

Berdasarkan tabel 7 diatas diketahui bahwa dimensi kebutuhan kekuasaan memiliki hubungan yang paling kuat dengan dimensi taat terhadap standar yaitu sebesar 0,789 atau $78,9 \%$. Hal tersebut menunjukan bahwa dengan karyawan ingin memiliki kekuasaan maka karyawan dapat bekerja sesuai dengan standar yang diterapkan oleh suatu organisasi. Pada dimensi pekerjaan diketahui memiliki hubungan paling kuat dengan dimensi kehadiran yaitu sebesar 0,700 atau $70 \%$. Hal tersebut mengindikasikan bahwa faktor kunci karyawan memiliki kehadiran yang sangat baik yaitu karena faktor pekerjaan yaitu karyawan menyadari bahwa pekerjaaan adalah hal yang paling penting dalam meningkatkan disiplin kehadiran karyawan. Pada dimensi pembayaran upah secara langsung memiliki hubungan yang paling kuat dengan dimensi kehadiran karyawan yaitu sebesar 0,705 atau 70,5\%. Hal ini berarti dimensi pembayaran upah secara langsung merupakan faktor kunci kehadiran karyawan dapat selalu baik dan karyawan disiplin dalam kehadiran untuk bekerja dengan baik. 
PEMBAHASAN

1. Pengaruh Motivasi terhadap Disiplin Kerja

Motivasi berpengaruh terhadap disiplin kerja karyawan kontrak Politeknik Negeri Jakarta. Artinya semakin tinggi motivasi karyawan dalam bekerja maka akan semakin tinggi disilpin kerja dan semakin rendah motivasi kerja karyawan maka semakin rendah disiplin kerjanya. Karyawan yang memiliki motivasi ingin menjadi karyawan yang terbaik maka karyawan tersebut akan bekerja dengan disiplin yang tinggi. Hasil penelitian tersebut juga sesuai dengan hasil penelitian dari Trio Saputra (2015), yang menyatakan bahwa motivasi kerja memiliki pengaruh yang signifikan terhadap disiplin kerja.

2. Pengaruh Kepuasan Kerja terhadap Disiplin Kerja

Kepuasaan kerja berpengaruh terhadap disiplin kerja karyawan kontrak Politeknik Negeri Jakarta. Kepuasan kerja merupakan cara pandang pegawai menyangkut pekerjaan yang dihadapinya baik mengenai pekerjaan maupun faktorfaktor tertentu dalam pekerjaan tersebut. Kepuasan kerja bersifat individual dan tergantung pada persepsi seseorang tentang apa yang dirasakannya mengenai pekerjaan. Demikian juga setiap individu akan memiliki tingkat kepuasan yang berbeda dengan nilai yang berlaku pada dirinya. Semakin banyak aspek-aspek dalam pekerjaan yang sesuai dengan keinginan tersebut, maka semakin tinggi kepuasan yang dirasakannya dan juga sebaliknya. Hal ini sangat erat kaitannya dengan pendapat Malayu S.P Hasibuan (2007:203), kepuasan kerja sangat mempengaruhi tingkat kedisiplinan karyawan, artinya jika kepuasan diperoleh dari pekerjaan maka kedisiplinan karyawan baik. Sebaliknya jika kepuasan kerja kurang tercapai dari pekerjaannya maka kedisiplinan karyawan rendah. Hasil penelitian tersebut juga sesuai dengan hasil penelitian dari Muhammad Abdul Hadi
(2012), yaitu secara parsial tersebut, kepuasan kerja yang dirasakan para karyawan baik kepuasan finansial, kepuasan sosial maupun psikologi dapat mempengaruhi disiplin kerja karyawan PT. Bank Tabungan Negara (Persero) Kantor Cabang Syari'ah Malang.

3. Pengaruh Kompensasi terhadap Disiplin Kerja

Kompensasi berpengaruh terhadap disiplin kerja karyawan kontrak Politeknik Negeri Jakarta. Menurut (Sikula, 2012) kompensasi adalah segala sesuatu yang dikonstitusikan atau dianggap sebagai suatu balas jasa atau ekuivalen. Remunerasi adalah suatu hadiah, pembayaran, atau balas jasa untuk jasa yang diberikan). Menurut (Hasibuan, 2012) kompensasi adalah semua pendapatan yang berbentuk uang, barang langsung atau tidak langsung yang diterima pegawai sebagai imbalan atas jasa yang berikan kepada perusahaan. Karyawan yang mendapatkan kompensasi yang layak maka akan meningkatkan disiplin dalam bekerja dan apabila Organisasi memberikan kompensasi yang tidak sesuai dengan keinginan karyawan maka mereka akan tidak disiplin dalam bekerja. Oleh karena itu, sudah sepantasnya organisasi memberikan kompensasi yang layak dan yang dapat membuat karyawan dan keluarganya menjadi nyaman dan mencukupi kebutuhan hidup dan kebutuhankebutuhan lainnya. Hasil penelitian tersebut sesuai dengan hasil penelitian dari Puput Maretha Sari, dkk (2015), yaitu kompensasi berpengaruh signifikan terhadap Disiplin kerja.

4. Pengaruh Motivasi Kerja, Kepuasan Kerja, dan Kompensasi secara bersama sama terhadap Disiplin Kerja.

Motivasi, kepuasan kerja dan kompensasi secara simultan berpengaruh terhadap disiplin kerja karyawan kontrak Politeknik Negeri Jakarta. Hasil penelitian tersebut sesuai dengan hasil penelitian dari Galih Rakasiwi (2014), 
yaitu terdapat pengaruh yang siginifikan motivasi, kepuasan kerja dan kompensasi secara simultan terhadap disiplin kerja Pada Satuan Polisi Pamong Praja Kabupaten Karanganyar. Disiplin kerja dapat ditingkatkan dengan meningkatkan motivasi, kepuasaan kerja, dan kompensasi pada pegawai kontrak di Politeknik Negeri Jakarta. Motivasi merupakan suatu kehendak atau keinginan yang muncul dalam diri karyawan yang menimbulkan semangat atau dorongan untuk bekerja secara optimal guna mencapai tujuan.

\section{PENUTUP}

Kesimpulan. Berdasarkan hasil penelitian mengenai pengaruh motivasi kerja, kepuasan kerja, dan kompensasi terhadap disiplin kerja karyawan kontrak di Politeknik Negeri Jakarta, dapat disimpulkan beberapa hal sebagai berikut:

1. Motivasi berpengaruh terhadap disiplin kerja karyawan kontrak Politeknik Negeri Jakarta. Apabila kebutuhan berprestasi, berafiliasi, dan kekuasaan terpenuhi dengan baik maka karyawan akan menunjukan disiplin kerja yang mencakup kehadiran yang tepat waktu, taat pada peraturan perusahaan atau organisasi, dan taat pada standar kerja dan penilaian yang ada berlaku.

2. Kepuasaan kerja berpengaruh terhadap disiplin kerja karyawan kontrak Politeknik Negeri Jakarta. Karyawan yang puas dengan pekerjaan, atasan, teman kerja, peluang promosi, dan working condition maka karyawan tersebut akan disiplin dalam bekerja terutama disiplin dalam kehadiran, taat pada peraturan, dan taat pada standar.

3. Kompensasi berpengaruh terhadap disiplin kerja karyawan kontrak Politeknik Negeri Jakarta. Hal tersebut mengindikasikan bahwa karyawan yang mendapatkan kompensasi yang layak pada pembayaran upah secara langsung, pembayaran upah tidak langsung, dan ganjaran non tunai akan meningkatkan kehadirannya, taat pada peraturan kerja dari organisasi dan taat pada standar yang ada di dalam organisasi.

4. Motivasi, kepuasan kerja, dan kompensasi secara simultan berpengaruh terhadap disiplin kerja karyawan kontrak Politeknik Negeri Jakarta. Artinya karyawan yang memiliki motivasi, kepuasaan kerja, dan kompensasi yang tinggi maka disiplin kerjanya pada aspek kehadiran, taat pada peraturan, dan taat pada standar akan tinggi pula.

\section{DAFTAR PUSTAKA}

Alibar, muslim. 2008. Faktor-Faktor yang Mempengaruhi Disiplin Kerja Pegawai Pada Biro Sekretariat Jendral Departemen Hukum dan HAM RI.

Bharata, Andhi. 2016. The Influence of Compensation and Training Toward Work Dicipline and Its Impact on The Employee Performance in Research Center of Science and Technology (PUSPITEK).

Brahmasari, Ayu, Ida dan Siregar, Peniel. 2009. Pengaruh Budaya Organisasi, Kepemimpinan Situasional dan Pola Komunikasi Terhadap Disiplin Kerja dan Kinerja Karyawan pada PT Central Proteinaprima Tbk.

Dessler, Gary. Fundamental of human resource management. 2011. Pearson Publishing Limited.

Dharmawan, Yusa, Made, I. 2011. Pengaruh Kompensasi dan Lingkungan Kerja Non Fisik Terhadap Disiplin dan Kinerja Karyawan Hotel Nikki Denpasar.

Dila, Nasyahta, Afidah dan Rohmah, Nurul, Thinni. 2015. Analysis of Efect Communication, Leadership, and Teamwork for Employee. Dicipline of $X$ Hospital Surabaya.

Drever, James. 1952. Dictionary of Psychology. Penguin Books. 2 second edition. Didigitalkan 1 Okt 2008

Fairchild, Henry, Pratt. 1994. Dictionary of Sociology. Philosophical library.

Ghazali. I. 2005. Aplikasi Analisis M ultivariate Dengan Program SPSS. UNDIP Semarang.

Hasibuan, M.S.P. 1990. Manajemen Sumber Daya Manusia. PT Gunung Agung, Jakarta.

Hasan, Dede. 2002. Kemampuan Manajerial Pimpinan Dalam Memotivasi dan Mendisiplinkan Karyawan Dikaitkan 
Dengan Produktifitas Kerja. Pps UPI, Bandung. Tesis tidak dipublikasikan.

Indriawan, Dicky, Ryan dan Sujanto Bejo. 2014. Hubungan Antara Kompensasi Dengan Disiplin Guru di SMA Global Islamic School Jakarta.

Jaya, Prawira, Yudi, Kadek dan Adnyani, Ayu, Gst, I. 2015. Pengaruh Gaya Kepemimpinan Terhadap Disiplin Kerja Pegawai di Dinas Bahasa Balai Bahasa Propinsi Bali.

Luthans, Fred. Psychology capital. 2006. Print ISBN-13: 9780195187526. Published to Oxford Scholarship Online: September 2007

Mulyani, Wiwit \& Bahtiar ,Muhamad. 2005. Hubungan Antara Motivasi Kerja Dengan Disiplin Kerja PNS. Thesis Pascasarjana

Maquarrie, John. 2012. Three Issues in Ethics. Hymns Ancient \& Modern Ltd. 1st edition

Saydam, Gouzali. 2005. Manajemen Sumber Daya Manusia : Suatu Pendekatan Mikro . Djambatan, Jakarta.

Lewin, Kurt. 1997. Resolving Social Conflicts and Field Theory in Social Science. American Psychological Association (APA).

Ma'ruf. 2007. Pengaruh Supervisi Kepala Sekolah dan Etos Kerja Terhadap Disiplin Kerja Guru SMKN Negeri Lampung Tengah.

Maslow. H. Abraham. 1994. Motivasi dan Kepribadian. PT PBP, Jakarta
McClelland, C, David. 1975. Power: The Inner Experience. Halted Press. New York.

Muslimah, Ani. 2007. Hubungan Kompensasi dan Kepuasan kerja Dengan Disiplin Kerja Petugas Pamong Praja Kota Bogor.

Prasojo, Sigit. 2005. Hubungan Karakteristik dan Motivasi Dengan Disiplin Kerja Perawat Pelaksana di Ruang Rawat Inap RSUD Batang.

Priljantiri. 2010. Pengaruh Motivasi dan Kepuasan Kerja terhadap Prestasi Kerja PT.Yonasindo Indo Pratama.

Singodimedjo, Markum. 2011. Manajemen Sumber Daya Manusia. SMMAS. Surabaya

Soehani. 2006. Kompensasi, Kepuasan Kerja dan Keterkaitanya Dengan Disiplin Kerja Petugas Lembaga Pemasyarakatan Pria Tangerang.

Sumenge, Alicia. 2016. Analytical of Compensation Factor, Job Stress and Motivation Campaign Against Occupation and Work Discipline and Its Effect on Employee Performance (A Study on the Employees of PT PLN (Persero) Region Suluttenggo) 